\title{
Multimedia Application Development With Islamic Critical Reflection Through 3-2-1 Technique for Novice Teacher Internship Program
}

\author{
Evi Fatimatur Rusydiyah ${ }^{1,}{ }^{*}$, Rakhmawati Rakhmawati ${ }^{1}$, Eni Purwati ${ }^{1}$, Moh. Hafiyusholeh ${ }^{2}$, Ahmad Hanif Asyhar $^{2}$ \\ ${ }^{1}$ UIN Sunan Ampel Surabaya, Faculty of Education and Teacher Training, Indonesia \\ ${ }^{2}$ UIN Sunan Ampel Surabaya, Mathematics Department, Indonesia
}

A R T I C L E I N F O
Article history:
Received: 20 April, 2019
Accepted: 30 April, 2019
Online: 24 May, 2019

Keywords:

Macromedia Flash

Islamic Critical Reflection

Research and Development
A B S T R A C T

The use of technology in the learning process has become the most significant point in helping teachers reaching the objectives of the learning. This study focuses on the use of multimedia by novice teachers in comprehending the internship program's guidance. The Islamic Critical Reflection model is a new and innovative model in the field of education which development is a result of integration between Islamic value and science. This study aims to answer problems related to the internship supervision which occurs among novice teachers. The multimedia application in the form of Flash Macromedia is developed using Islamic Critical Reflection model for internship program of novice teachers at the Tarbiyah and Teacher Training Faculty UIN Sunan Ampel Surabaya. The research design of this study is Research and Development. It includes the process of collecting information, designing a product, validating the design, improving the design, piloting the product, rerevising the product, trying out the product, revising further and creating products for large numbers. The results of this study indicate that the products produced by Macromedia Flash application integrated with Islamic Critical Reflection Model for Tarbiyah and Teacher Training Faculty of UIN Sunan Ampel Surabaya's internship program are feasible to use. The results are from the experts' analysis and users' trials. Experts involved in the validation of this product are Islamic Education specialists, application experts, educational technology experts, and curriculum expert.

\section{Introduction}

UIN Sunan Ampel Surabaya has a vision and mission that is hoped to be reached through the milestones between the period of 2019-2045. The milestones are described in the UIN Sunan Ampel Surabaya's Development Master Plan 2019-2045 [1], [2]. One of the biggest duty of UIN Sunan Ampel Surabaya and also of other higher education institutions managed by the Ministry of Religion is to integrate knowledge and religion as the differentiator between the institutions with those managed by the Ministry of Education.

Higher education nowadays has more challenging responsibility in preparing its students to be ready for the 4.0 industrial revolution. This preparation can be managed by an internship program for novice teachers. It is because this module is an integration between theory and practice done at schools. This program aims to prepare students to be professional teachers.

* Evi Fatimatur Rusydiyah, Jl. A. Yani 117 Surabaya, +62 8121635409 \& evifatimatur@uinsby.ac.id
Within this context, UIN Sunan Ampel has done many adaptation programs. One of the programs is designed to train novice teachers in mastering teaching skill that is intact and integrated. Therefore, after graduating, novice teachers who have taken the internship module are hoped to be ready for teaching [3], having a positive identity as a teacher, and acquiring more knowledge in the field of teaching [3]. It is possible because the internship program has several elements that are involved: supervisor, mentor teacher, and novice teacher.

The challenge is that the internship program that is running at the moment is considered to be not effective and not efficient yet in its guidance system. The problem that is emerged is the unstructured guidance program within each element. The evaluation and reflection in the internship program have only been partially conducted without a thorough involvement of various weakness points. The result is, there is no comprehensive information toward the development of novice teachers during the internship program. This condition then resulted in less competent novice teachers. Whereas, this internship program is designed to 


\section{E.F. Rusydiyah et al. / Advances in Science, Technology and Engineering Systems Journal Vol. 4, No. 3, 100-105 (2019)}

be the prime program the faculty can offer, and also designed to be the educational core program.

To resolve the problem, Tarbiyah and Teacher Training faculty strives to develop a supervision system through critical reflection approach in the internship program. The technique implemented is the 3-2-1 technique with Islamic values as the base of its integration. Therefore, the process will facilitate teaching and learning, and it would be central to the teacher's development. The implementation of the 3-2-1 technique is done within the discussion process between the supervisor, mentor teacher and novice teacher. The three elements provide three positive inputs of what was found during the internship. After that, two negative inputs are presented and followed by a solution [4]. The Islamic Critical Reflection approach is used during supervision. It is based on Surah Al-Hujurat verse 6-8.

In this research, the concept is made in the form of the application using Flash Macromedia. Included in it, is the first supervision until the eighth. In other words, this research aims to develop a multimedia application with Islamic Critical Reflection for the Novice Teacher Internship Program.

In this research, multimedia as a tutorial application in facilitating teacher mentors, lecturers, and students in carrying out practical activities in field experience, so that they can understand the steps of supervision they will do for each. For teacher mentors, they will understand what they must provide in each supervision. For lecturers, they can understand what must be done when they are supervised. Likewise, for students, they will understand what they should get every time the lecturer supervises. Therefore this multimedia is not used for the learning process in the classroom, but this multimedia is used as a tutorial application in making supervising steps clear.

With the application, it is hoped that the novice teacher's professionalism is improving in the way that novice teachers can critically reflect and integrate it with Islamic values and pedagogical knowledge. "Critical reflection involves concern about the broader issue of teaching and learning" [5] is the notion that Murray and Kujundiz hold. They explained that [6] "critical reflection involves a process of analyzing, reconsidering, and questioning experiences within a broad context of issues such as analyzing assumption about teaching, raising awareness about the context of teaching. They imagine alternative ways of thinking".

The concept is visualized in the form of flash Macromedia. The application is developed through the Technology Acceptance Model (TAM). TAM model modification is done by Venkantesh [7] by adding trust variable with the title: Trust enhances Technology Acceptable Model which evaluating the relationship between TAM variable and trust. TAM other modification is Trust and Risk in Technology Acceptance Model (TRITAM) that uses trust and risk variable named TAM variable [8]. This model is one of the models developed from the theory of using a system of technology. It is considered to be the most affected in explaining personal acceptance towards the benefit and information technology used as a system [9].

One research that is related to the novice teacher program is Toman et al., [10]. It develops reflective thinking method and determines the novice teacher reflective thinking level. In 2007, Mathew discussed how mentor teacher creates opportunities for the novice teachers to developed reflective practice during the internship at school [11]. Gonen [12] in the research that was aimed to evaluate the experience that caused some changes after reflection is done. Moreover, it was also aimed to figure out what experience gained by the novice teacher after receiving guidance from the mentor teacher [12].

The importance of this research is for both the mentor teacher and the novice teacher understand the supervision process thoroughly, especially in implementing the 3-2-1 reflective principal as a part of novice teacher professional development. Novice teacher will be more confident with the guidance process that used Islamic Critical Reflection. Mentor teacher will also work professionally in guiding novice teacher.

\section{Design}

This research is aimed to develop an application in the form of Macromedia flash to be used in the internship program. This multimedia application is used to make an understanding of the duties of lecturers, mentor teacher,, and novice teacher when conducting internship program as a tutorial in supervising. Therefore this application is not used in class as media teachinglearning but is used in the supervision process. According to Borg and Gall [13], this research is categorized as Research and Development (R\&D) research.

Steps that are generated from the process are understood to be the R\&D cycle. They are consisted of studying research findings, developing the product, testing the product, and revising it to improve its weaknesses.

The R \& D design used in this study is as follows.

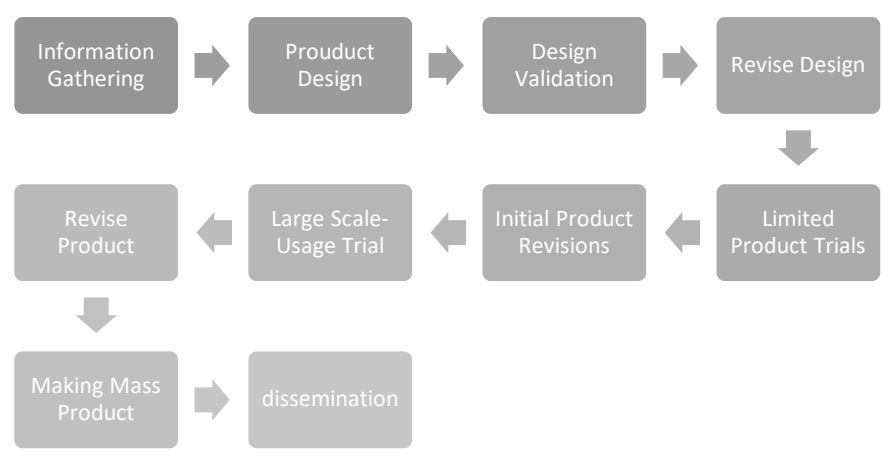

Figure 1. R \& D flow

The R \& D steps as referred to in the figure are information gathering, product design, design validation, revise design, limited product trials, initial product revisions, large-scale usage trials, revise product, making mass product, and dissemination [13]. These steps are a guide for researchers to conduct this research.

The test subjects in this $\mathrm{R} \& \mathrm{D}$ are stakeholders involved in implementing the practice of the field experience. The 
stakeholders are 50 partner schools of the Tarbiyah Faculty UIN Sunan Ampel Surabaya which are occupied by field experience, 50 supervisors, and 150 mentor teachers.

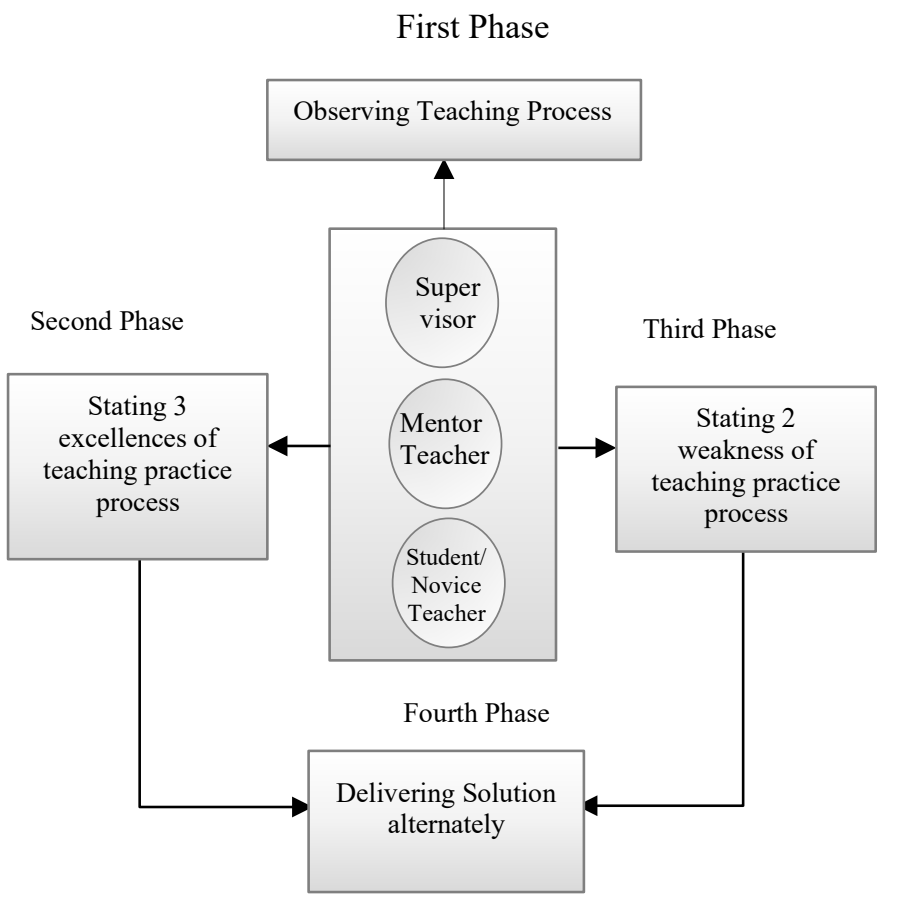

Figure 2: Islamic Critical Reflection Model

The product produced is based on the Islamic Critical Reflection model. This is a distinction as UIN Sunan Ampel integrated its learning process to Islamic principles and research [14], [10], [12]. The steps in Islamic Critical Reflection are observation, advantages, deficiency, and solution. The scheme can be seen in Figure 2.

The instrument which is used to measure the product is the Technology Acceptance Model (TAM). It is to explain personal acceptance towards the benefit and the use of information technology as a system [9]. After the application is made, the validity test was conducted. The experts to validate were ones who are expert in Islamic Education, Technology Education, and Curriculum. Operational suitability of the product was conducted in ten different primary schools and secondary school in Surabaya and Sidoarjo, East Java. The questionnaire was the main instrument for this stage.

\section{Finding and Discussion}

As in the R \& $\mathrm{D}$ design above some of the findings in this study are as follows:

\subsection{Gather Information}

Information about the implementation of internship program in schools was conducted on Sunday, May 13, 2018 through a Focus Group Discussion (FGD) which was attended by 47 good tutors who were in Ibtidaiyah Madrasah, Madrasah Tsanawiyah / Middle School, Islamic Senior High Schools/ Vocational Schools in the region Surabaya and Sidoarjo and 41 Supervisors at the Sunan Ampel State Islamic University (UINSA). The FGD results show the need for understanding the concept of how the guidance model can improve the quality of UINSA internship's students who are qualified, the need for easy access that can be reached by students, civil servant teachers and Field Supervisors about guidelines for implementing effective and efficient internship program.

\subsection{Stage of Product Design}

On June 5, a Forum Group Discussion (FGD) was held which was attended by experts, namely educational technology experts, multimedia experts, Islamic education experts, and curriculum design experts from development products including a model of student assistance with Pamong Teachers and Field Advisors with 3-2-1 (triad meeting) which is visualized in Flash Media Media multimedia. On June 10, an FGD was held which was attended by experts again by presenting users. This FGD designed a product that will be formed in the internship application development model using Islamic studies on how to provide critical assistance based on an Islamic approach.

At this stage it was found, the practice of field training needs to be done with a reflective approach in communicating to convey information. This 3-2-1 approach is an implementation of Islamic teachings, that motivating students must be done politely with techniques to promote positive aspects rather than negative aspects. Likewise, the technique 3-2-1 strengthens the process of training students in finding solutions based on an analysis of their strengths and weaknesses [6]. Therefore approach 3-2-1 is an approach that leads to the analysis of the theory of critical reflection.

The 3-2-1 approach is also supported by the pyramid theory of human needs from Malow [15]. Humans in their lives have different needs, those needs from the high to the low. The lowest needs are the need to acknowledge oneself, then the need for compassion, love and love, then the need for security, and the highest needs are physiological needs. The higher the education of a person the higher the level of recognition desired [16]
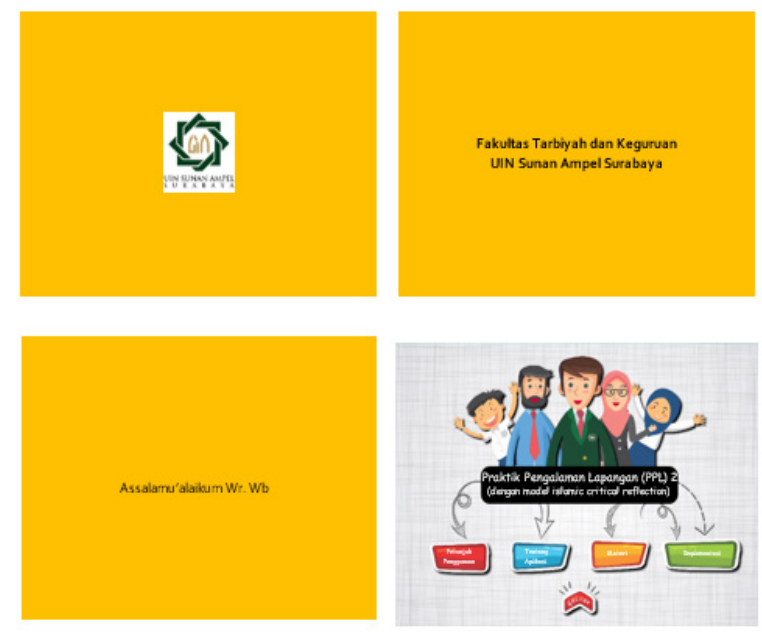

Figure 3: Preliminary Display of the Pre Service Teacher Interference Model Application through the Islamic Critical Reflection Approach

\subsection{Stage of Validation Design}

The validators involved in this study were 1) Islamic religious education experts, multimedia experts, learning technology 


\section{E.F. Rusydiyah et al. / Advances in Science, Technology and Engineering Systems Journal Vol. 4, No. 3, 100-105 (2019)}

experts, and curriculum experts. The results of the validator are as follows.

\section{Islamic Education Expert}

The application was developed through several steps. The first one is the observation step based on the basic Islamic teaching, which is Surah Al Maidah verse 17 and surah Al-Anam verse 46 about observing the process as one of Allah's power. In observing the novice teacher, mentor teacher could see how a novice teacher is going through a process in becoming a professional teacher and how a novice teacher is going through a process to be better.

The second and third step is to give a positive and negative suggestion. The second and the third step is the feedback from the supervisor, mentor teacher, and novice teacher. They all work together to suggest positive points. The inspiration for this step is Surah Al Baqarah verse 219, Surah Al Haj verse 28, Surah Al Isra' verse 14 and Surah Al Ankabut verse 3. Based on the verses, it can be concluded that as a supervisor, a mentor teacher, and a novice teacher, all the three elements have to deliver the truth, which is: conveying positive points to understand the deeper meaning, to contemplate, to evaluate the positive and the negative sides. Contemplation is designed by giving three positive characters and two negative experience.

The fourth step is the solution stage. It is based on Surah Al Baqarah verse 153, Surah Al Baqarah verse 109, Surah Al Ahzab, verse 70-71. All of the surah mentioned gives a clue that supervisor, mentor teacher and novice teacher have to show positive attitude such as to talk politely.

To ease the user in operating the application, guidance and summary result were provided thoroughly as it is seen in Figure 4.
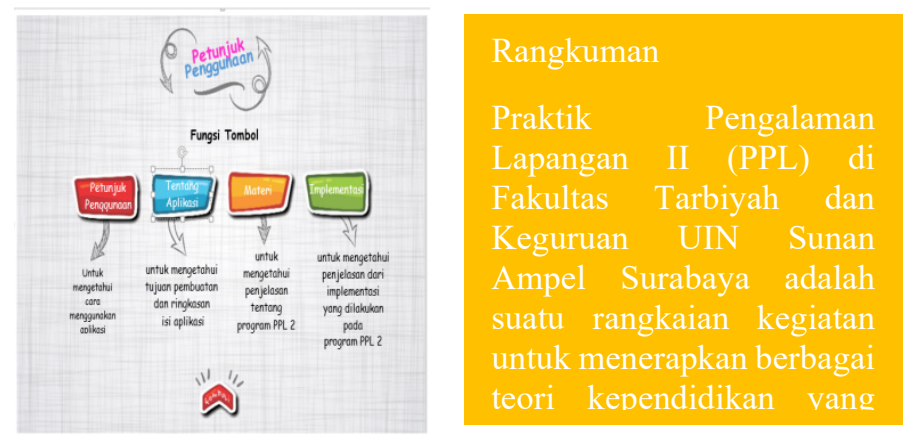

Figure 4: Application Guidelines And An Application Summary

The Macromedia flash application consists of application guidelines, internship material, supervision stages, stages on supervision using the 3-2-1 technique. The third is to show the positive sides of the novice teacher's teaching. The second is to show the weaknesses of the novice teacher's teaching, and the first one is the solution. The 3-2-1 technique was used in a discussion and is conducted when the supervisor supervises the novice teacher. The 3-2-1 technique will be used not only by the novice teacher but also as a supervisor.

The result of the research is suitable with Maslow concept about human need pyramid. It is said that human need recognition.
The recognition needed is toward self-actualization, affection, safety, and psychological needs [15]. Those needs are basic human needs. It also supported by several research: Schulte dan Marthann [17], Medcalf et all[18], Emad [19] dan Sari dan Dwiarti [20]. These research found out that motivation has a significant effect on work and study achievement.

The result of this 3-2-1 reflection technique is hoped to shape the novice teacher's self-confident. The teaching and learning will result in positive, and novice teacher can find their professionalism through reflecting every meeting. Therefore, they will be a professional teacher.

\section{Application Analysis}

The application that has been made was measured for its suitability using TAM indicator which consists of Perceived of Usefulness with its sub-indicators as follow: 1) Make Job Easier; 2) Work More 3) Increase Productivity 4) Effectiveness 5) Improve job performance (6) Useful. The second indicator is Perceived ease of use with its sub-indicator as follow: 1) Easy to learn 2) Controllable 3) Clear and understandable (4) Flexible, 5) Easy to become skillful (6) easy to use [21]. This research also used an application that was developed based on the humanmachine interaction [22] indicator by Davis [23] and Hendrawati [24]. It has several indicators, such as learnability, efficiency, memorability, errors, and satisfaction.

Through the application, it is gained several positive aspects as follow: the application could give guidance for a supervisor so that the supervisor could use it easily. It could also aid the supervisor's understanding in guiding a novice teacher. It helps the supervisor to improve novice teachers' professional competencies. This application is designed to present steps in supervising internship programs using the 3-2-1 technique effectively. This, in return, beneficial for faculty, supervisors and lecturers, novice teachers, school and stakeholders to develop teachers' professionalism.

Based on the application analysis, it is found out that the application design using buttons that are familiar for users is compatible with these Operating System: Windows, Linux, and Android. This development supports Koral and Emel [25], also Akar and Güzin [26] who suggest that technology acceptance relates to content comprehension which becomes the focus. It is also stated by Konak et al. [27] who stated that technology acceptance affects collaborative work. The same notion explained by Davis [21] and Hendrawati [24] who figured that technology acceptance had affected intrinsic motivation to occur.

As the previous research, information technology system acceptance could be explained within group work. The bigger the group who receive the information technology system, the bigger its practice would change. The group would also tend to use or try something new that could be used or developed in an information technology system

\subsection{Education of Technology analysis}

Education technology is a knowledge which relates to theory and practice on how to design, develop, implement, organize, and measure the education process to reach the educational aim. One 


\section{E.F. Rusydiyah et al. / Advances in Science, Technology and Engineering Systems Journal Vol. 4, No. 3, 100-105 (2019)}

of its important components is a reflection. Reflection is a stage in an educational process so that the goal is reached. Therefore, reflection is used as one of the stages in this application so that it would affect novice teacher positively.

This condition is the same as several research which stated that every novice teacher has a reflective thinking skill [10]. Novice teacher has contributed positively towards the teaching skill that is developed to think reflectively [11]. Reflective needs to be applied when conducting an internship [12].

The same notion goes to video animation. The message is delivered effectively using video. The research that was conducted by Duygu Sonmez and Meral Hakverdi-Can [28] explained that video and application could affect users' comprehension in teaching reflectively.

The result of this study support the research by Mohd dan Elmagzoub A [29], Komalasari, et al. [30], Djamas, et al. [31], and Richter research's [32]. These researchers found out that learning through application brings a positive effect to the learning result. In this research, it was also found that the mentor teacher understood it more on how to do supervision job during the internship. Likewise the results of research conducted by DeVore et al. [33], Linton [34], Hamdi, et al. [35] Syurigin and Krasnova [36], Lailiyah et al. [37] and Darmawan [38].

\subsection{Curriculum Analysis}

During the internship program, eight supervisions were conducted. The internship was for two months on holiday between July and September every year [3]. The first supervision is an introduction, observation, school introduction, and sit in with mentor teacher as a complete model. The three activities were conducted in the first week within the supervision activity.

The second supervision is a practical observation which was guidance teaching (with the composition of mentor teacher took up $75 \%$ and novice teacher took up $25 \%$ ) and conference (discussion between mentor teacher, supervisor and novice teacher) on a learning process that has been conducted and lesson plan preparation. Other points that were discussed were: practical guidance teaching (mentor teacher took up 50\%, and novice teacher took up 50\%), and conference (discussion between mentor teacher, supervisor, and novice teacher) about the learning process that has been conducted and lesson plan preparation. The second supervision was done in the second week.

The third supervision was a practical observation on guidance teaching (mentor teacher took up 25\%, and novice teacher took up 75\%) and a conference (discussion between mentor teacher, supervisor, and novice teacher) on the learning process that has been conducted and lesson plan preparation. This supervision was conducted in the third week of the internship program.

The fourth supervision is a practical observation on independent teaching and a conference (discussion with a mentor teacher, supervisor and novice teacher) on the learning process that has been conducted and lesson plan preparation. This was done in the fourth week.

The fifth supervision is on the fifth week. The supervision was a practical observation on independent teaching and a conference (discussion between mentor teacher, supervisor, and novice teacher) on the learning process that has been conducted and lesson plan preparation.

The sixth supervision is a practical observation on independent teaching and a conference (discussion between mentor teacher, supervisor, and novice teacher) on the learning process that has been conducted and lesson plan preparation. The seventh supervision is a practical observation on independent teaching and a conference (discussion between mentor teacher, supervisor and novice teacher) on the learning process that has been conducted and lesson plan preparation. This was conducted during the sixth week during the internship program. The eighth supervision was an observation on presentation preparation about the internship result and the finishing of the report. This was done in the sixth week.

The activities above can be visualized in a Macromedia flash application. This application was used in order to aid internship guidance comprehension in the means of attractive visual for users. Not only that, the internship guidance scheme as part of the curriculum becomes more organized and systematic. This is because each supervision has a clear aim and target and therefore, could improve the professionalism of novice teacher [16]. This process could be said as a professionalism improvement process by providing review activity in the reflection during the conference. This is also understood as the implementation of democracy in education [39].

The basis of this development and research is on the analysis of curriculum expert. The result was the internship curriculum design that will influence professionalism achievement of a novice teacher. This is as what Capka [40] has found that the curriculum design could influence student professionalism in the field of accountancy. Another research was by Jasperson [41] which stated that the internship curriculum with reflection principles could improve students' self-development. The same result was concluded by Johnson [42] who found that the internship process contributes to student's carrier development after graduation.

\section{Conclusion}

Internship model application development for novice teacher using the Islamic Critical Reflection was conducted based on four experts. The Islamic religion education expert stated that this application represents Islamic teaching principles as the basis of educational theory development. Application expert stated that this application meets the easiness and readability aspect of TAM (Technology Acceptance Model). Education technology expert stated that educational aspect through reflective teaching is used for feedback to improve the professionalism of novice teacher. It is found in this application. Curriculum expert stated that the cycle of 2-month supervision in this application is a good way in improving novice teacher's professionalism Conflict of Interest.

\section{Acknowledgment}

Our gratitude goes to UIN Sunan Ampel Surabaya for giving a research grant in 2018 .

\section{References}

[1] RIP UIN Sunan Ampel Surabaya Tahun 2019-2045, 


\section{E.F. Rusydiyah et al. / Advances in Science, Technology and Engineering Systems Journal Vol. 4, No. 3, 100-105 (2019)}

[2] "Peraturan Menteri Agama Republik Indonesia Nomor 56 Tahun 2015 Tentang Statuta Universitas Islam Negeri Sunan Ampel Surabaya." p. 6.

[3] Tim Penyusun, Buku Panduan PPL I Fakultas Tarbiyah dan Keguruan Universitas Islam Negeri Sunan AMpel. 2017.

[4] A. Fred and J. P. A. M. Kessels, "Linking Theory and Practice: Changing the Pedagogy of Teacher Education."

[5] T. Gale, "Preparing Professionals: student teachers and their supervisors at work Asia-Pacific Journal of Teacher," no. November 2018.

[6] M. Murray \& Kujundzic, N, critical Reflection: A text book for critical thinking. quebec. Canada: McGill-queens University Press, 2005.

[7] Venkatesh, Morris, and Davis, "User Acceptance of Information Technology: Toward a Unified View," MIS Q., vol. 27, no. 3, p. 425, 2017.

[8] H. K. Lui and R. Jamieson, "eTransformation TRiTAM: A Model for Integrating Trust and Risk Perceptions in Business-to-Consumer Electronic Commerce," Methodology, no. September 2001, pp. 349-364, 2003.

[9] Jogiyanto, Sistem Informasi Keperilakuan. Yogyakarta: ANDI Offset, 2008.

[10] T. Ufuk, "Analysis Of Pre-Service Science Teachers' Views About The Methods Which," no. October, pp. 179-189, 2014.

[11] J. Peechattu, "Reflective practices: a means to teacher development," pp. 16, 2017.

[12] S. I. K. Gonen, "A Study on Reflective Reciprocal Peer Coaching for Preservice Teachers : Change in Reflectivity," vol. 4, no. 7, pp. 221-235, 2016.

[13] J. P. G. Gall Walter R. Borg, Educational research: an introduction / Meredith D. 1942.

[14] M. Harvey, "Editorial - Reflection for Learning in Higher Education," vol. 13, no. 2, 2016.

[15] A. H. Maslow, "Toward a Psychology of Being. A Psychology Classic." Start Publishing LLC, 2012

[16] E. Rusydiyah, "Rehearsal Model as the Practicum Model in Preparing Professional Pre-service English Teachers," in International Conference on English Language Teaching (ICONELT 2017), 2017.

[17] M. Schulte, "Adult Learning Degree and Career Pathways: Allusions to Maslow's Hierarchy of Needs," J. Contin. High. Educ., vol. 66, no. 1, pp. 62-64, 2018

[18] N. A. Medcalf, T. J. Hoffman, and C. Boatwright, "Children's dreams viewed through the prism of Maslow's hierarchy of needs," Early Child Dev. Care, vol. 183, no. 9, pp. 1324-1338, 2013.

[19] G. Emad, "Self-fulfillment development among the Arab sector in Israel," $J$. Educ. Train. Stud., vol. 5, no. 5, pp. 81-92, 2017.

[20] E. Sari and R. Dwiarti, "Pendekatan Hierarki Abraham Maslow pada prestasi kerja karyawan PT. Madubaru (PG Madukismo) Yogyakarta," J. Perilaku dan Strategy. Bisnis, vol. 6, no. 1 February, pp. 58-77, 2018.

[21] J. Fred D. Davis, "A Technology Acceptance Model For Empirically Testing New End-User Information Systems: Theory And Results," 1985.

[22] F. D. Davis, R. P. Bagozzi, and P. R. Warshaw, "Extrinsic and Intrinsic Motivation to Use Computers in the Workplace' FRED D. DAVIS ," 1992.

[23] J. Fred D. Davis, "A Technology Acceptance Model For Empirically Testing New End-User Information Systems: Theory And Results," 1985.

[24] T. Hendrawati, "Analisis Penerimaan Sistem Informasi Integrated Library System ( Inlis )," Visi Pustaka, vol. 15, no. 3, 2013.

[25] E. Koral Gümüsoglu and E. Akay, "Measuring Technology Acceptance Level of Teachers by Using Unified Theory of Acceptance and Use of Technology, Online Submission," Int. J. Lang. Educ. Teaching. v5, no. 4, pp. P378-394, 2017.

[26] M. Akar and S. Guzin, "A Structural Model for Relationship between Web Pedagogic Content Knowledge and Technology Acceptance of Preservice Teachers.," Malaysian Online J. Educ. Technol., vol. 7, no. 1, pp. 1-14, 2019.

[27] A. Konak, S. Kulturel-Konak, M. Nasereddin, and M. R. Bartolacci, "Impact of Collaborative Work on Technology Acceptance: A Case Study from Virtual Computing.," J. Inf. Technol. Educ., vol. 16, no. 1, 2017.

[28] D. Sonmez, "Videos as an Instructional Tool in Pre-service Science Teacher Education Meral Hakverdi-Can **," Eurasian J. Educ. Res., vol. 46, no. 46, pp. 141-158, 2012.

[29] M. Babiker and A. Elmagzoub, "For Effective Use of Multimedia in Education, Teachers Must Develop Their Own Educational Multimedia Applications.," Turkish Online J. Educ. Technol., vol. 14, no. 4, pp. 62-68, 2015.

[30] K. Komalasari and D. Saripudin, "Value-Based Interactive Multimedia Development through Integrated Practice for the Formation of Students' Character.," Turkish Online J. Educ. Technol., vol. 16, no. 4, pp. 179-186, 2017.

[31] D. Djamas and V. Tinedi, "Development of Interactive Multimedia Learning Materials for Improving Critical Thinking Skills," Int. J. Inf. Commun. Technol. Educ., vol. 14, no. 4, pp. 66-84, 2018.
[32] J. Richter, K. Scheiter, and A. Eitel, "Signaling text-picture relations in multimedia learning: A comprehensive meta-analysis," Educ. Res. Rev., vol. 17, pp. 19-36, 2016.

[33] S. DeVore, E. Marshman, and C. Singh, "Challenge of engaging all students via self-paced interactive electronic learning tutorials for introductory physics," Phys. Rev. Phys. Educ. Res., vol. 13, no. 1, p. 10127, 2017.

[34] J. N. Linton, "Institutional Factors for Supporting Electronic Learning Communities.," Online Learn., vol. 21, no. 1, pp. 238-256, 2017.

[35] A. Z. Hamdi, A. H. Asyhar, Y. Farida, N. Ulinnuha, D. C. R. Novitasari, and A. Zaenal, "Sentiment Analysis of Regional Head Candidate's Electability from the National Mass Media Perspective Using the Text Mining Algorithm."

[36] V. Y. Shurygin and L. A. Krasnova, "Electronic Learning Courses as a Means to Activate Students' Independent Work in Studying Physics.," Int. J. Environ. Sci. Educ., vol. 11, no. 8, pp. 1743-1751, 2016.

[37] S. Lailiyah, T. Nusantara, C. Sa'Dijah, E. B. Irawan, Kusaeri, and A. H. Asyhar, "Structuring students' analogical reasoning in solving algebra problem," IOP Conf. Ser. Mater. Sci. Eng., vol. 296, no. 1, 2018.

[38] D. Darmawan, H. Kartawinata, and W. Astorina, "Development of WebBased Electronic Learning System (WELS) in Improving the Effectiveness of the Study at Vocational High School" Dharma Nusantara".," JCS, vol. 14, no. 4, pp. 562-573, 2018.

[39] C. M. Reigeluth, Instructional Design theories and models. 1999.

[40] J. Capka and C. Foltin, "Policy Implications of a Proposed Framework to Improve the Accessibility and Effectiveness of Internships in Accounting.," eJEP eJournal Educ. Policy, 2017.

[41] J. O. Jasperson, "How to Integrate Student Internships into Legal Studies Research and Curriculum: A Case Study.," Univers. J. Educ. Res., vol. 5, no. 9, pp. 1504-1509, 2017.

[42] K. W. Johnson, "A Case Study Exploration of Internships in Undergraduate Business Education," 2018. 